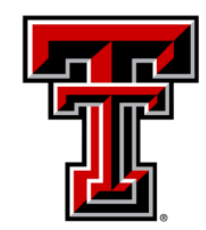

TEXAS TECH UNIVERSITY

Libraries"

\title{
COMPARISON OF MISCANTHUS AND SWITCHGRASS CULTIVARS FOR BIOMASS YielD, SOIL NUTRIENTS, AND NUTRIENT REMOVAL IN NORTHWEST SPAIN
}

\section{The Texas Tech community has made this publication openly available. Please share how this access benefits you. Your story matters to us.}

\begin{tabular}{|l|l|}
\hline Citation & $\begin{array}{l}\text { Oliveira, J.A., C.P. West, E. Afif, and P. Palencia. 2017. Comparison } \\
\text { of miscanthus and switchgrass cultivars for biomass yield, soil } \\
\text { nutrients, and nutrient removal in northwest Spain. Agron. J. 109: } \\
\text { 122-130. https://doi.org/10.2134/agronj2016.07.0440 }\end{array}$ \\
\hline Citable Link & $\underline{\text { https://hdl.handle.net/2346/86937 }}$ \\
\hline Terms of Use & $\underline{\text { CC BY-NC-ND 4.0 }}$ \\
\hline
\end{tabular}




\title{
Comparison of Miscanthus and Switchgrass Cultivars for Biomass Yield, Soil Nutrients, and Nutrient Removal in Northwest Spain
}

\author{
José Alberto Oliveira,* C. P. West, Elias Afif, and Pedro Palencia
}

\begin{abstract}
Comparative performance tests of perennial grasses for biomass yield, quality, and soil nutrient removal are needed to guide decisions toward meeting European Union targets for renewable energy production. We compared hybrid miscanthus (Miscanthus $\times$ giganteus Greef and Deuter ex Hodkinson and Renvoize) and switchgrass (Panicum virgatum L.) cultivars Cave-in-Rock, (upland type), Alamo, and Kanlow (lowland types) for biomass yield and changes in soil macronutrient levels and removal rates in a humid Spanish environment. Soil and plant nutrient and $\mathrm{C}$ levels were measured after each annual biomass harvest for 4 yr. Plant nutrient concentrations were multiplied by biomass yield to express nutrient removal. Yield ranking (4-yr mean) was miscanthus $\left(17.6 \mathrm{Mg} \mathrm{ha}^{-1}\right)>$ Kanlow $\left(13.3 \mathrm{Mg} \mathrm{ha}^{-1}\right)=$ Alamo $\left(13.0 \mathrm{Mg} \mathrm{ha}^{-1}\right)>$ Cave-in-Rock $\left(7.7 \mathrm{Mg} \mathrm{ha}^{-1}\right)$. Miscanthus biomass yield peaked in the third year at $27.0 \mathrm{Mg} \mathrm{ha}^{-1}$. The high yield of miscanthus together with its relatively low macronutrient concentrations and intermediate removal rates, indicate its advantages over switchgrass as a biomass crop choice. Alamo and Kanlow usually removed more macronutrients than Cavein-Rock, suggesting a greater long-term fertilizer requirement for the lowland types. Soil C stocks increased by a mean of $2850 \mathrm{~kg} \mathrm{ha}^{-1}$ over 4 yr at 0 - to 20 -cm depth. Phosphorus was the macronutrient most likely to become deficient after repeated harvests. Miscanthus and lowland switchgrass cultivars performed well in the Atlantic maritime region of Spain, therefore the choice of crop would rely on economics of establishment and long-term stand maintenance.
\end{abstract}

\section{Core Ideas}

- Miscanthus and switchgrass are often touted as biomass crop choices, but have rarely been compared side-by-side.

- Miscanthus was slower to establish than switchgrass cultivars, but out-yielded switchgrass in the latter 3 yr of the trial.

- Phosphorus was the soil nutrient most likely to be drawn down to levels requiring fertilization, after $\mathrm{N}$.

\section{Published in Agron. J. 109:122-130 (2017)}

doi:10.2134/agronj2016.07.0440

Received 27 July 2016

Accepted 12 Nov. 2016

Available freely online through the author-supported open access option

Copyright ( 2017 American Society of Agronomy

5585 Guilford Road, Madison, WI 53711 USA

This is an open access article distributed under the CC BY-NC-ND

license (http://creativecommons.org/licenses/by-nc-nd/4.0/)

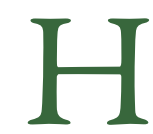

YBRID miscanthus and switchgrass have been suggested as high-yielding, low-input bioenergy feedstocks (Dohleman and Long, 2009; Heaton et al., 2008). Miscanthus and switchgrass can produce abundant biomass in Mediterranean conditions, but irrigation is needed to match their summer growth patterns (Curt, 2009). Atlantic maritime influence in northwestern Spain of summer rainfall and cooler temperatures would potentially provide a more favorable climate for these grasses compared with the Mediterranean conditions of central and southern Spain; however, their relative productive potentials and effects on soil in northwestern Spain are unknown (Hernández Díaz-Ambrona and Fuertes Sánchez, 2011). Miscanthus and switchgrass are widely adapted across subhumid to humid environments (Lewandowski et al., 1998; Sanderson et al., 1996), but sideby-side comparisons of these grasses and cultivars over several years are needed to predict the economic and biological potential of widespread exploitation.

Switchgrass, native to North America, is a warm-season (C4) perennial grass whose wide adaptation is due partly to the wide genotypic variation within switchgrass populations and cultivars (Casler et al., 2007). Miscanthus is a high-yielding perennial grass (C4) native to Asia and introduced in Europe in the 1930s (Linde-Laursen, 1993). Plantings are clonal, therefore plants within a cultivated population lack genotypic variability.

Although it is commonly stated that miscanthus has a higher yield potential than switchgrass (Clifton-Brown et al., 2001), only a few studies have compared them across the United States and Europe (Aravindhakshan et al., 2010; Heaton et al., 2004a; Khanna et al., 2008; Kiniry et al., 2012, 2013), and sometimes with contrasting results. Switchgrass showed higher annual yields in the first $2 \mathrm{yr}$ after establishment, after which the productivity of miscanthus was significantly greater than switchgrass from 3 to $6 \mathrm{yr}\left(14.96 \mathrm{Mg} \mathrm{ha}^{-1} \mathrm{vs}\right.$. $11.93 \mathrm{Mg} \mathrm{ha}^{-1}$, respectively; Lasorella et al., 2011). Likewise, the yield advantage of miscanthus over switchgrass cultivars in the Midwest United States disappeared further South, where water and nutrients become more limiting (Kiniry et al., 2012). It is important to assess these crops in side-by-side field trials to remove confounding environmental effects when comparing to literature sources that did not involve a common environment.

J.A. Oliveira and P. Palencia, Plant Production Area, Department of Organisms and Systems Biology, Polytechnic School of Mieres, Oviedo University, Mieres, 33600 Asturias, Spain; C.P. West, Plant and Soil Science Dep., Texas Tech University, Lubbock, TX, 79409; E. Afif, Agroforestry Engineering Area, Department of Organisms and Systems Biology, Polytechnic School of Mieres, Oviedo University, 33600 Mieres, Asturias, Spain. ${ }^{*}$ Corresponding author (oliveira@uniovi.es). 
For miscanthus and switchgrass to be economically successful for bioenergy production, they must maintain high yields over the long term (Arundale et al., 2014; Heaton et al., 2004b). Harvest time is an important consideration in miscanthus and switchgrass production, since delaying harvest time after the end of the growing season causes reductions in the yield, although this may be compensated by improvements in feedstock quality (Lewandowski and Heinz, 2003; Makaju et al., 2013).

The number of studies assessing the influence of switchgrass and miscanthus managed for bioenergy production on changes in soil fertility is limited (Skinner et al., 2012). Switchgrass stands exhibited a beneficial impact on soil fertility in semiarid land in China through alleviation of nitrate leaching and increase in soil microbial C (Molatudi et al., 2015). Schmer et al. (2011) showed that switchgrass would be a sustainable energy crop in the northern and central Great Plains and adjacent Midwest United States because of its role in soil $\mathrm{C}$ sequestration and its minimal impact on other important soil properties. Miscanthus also exhibited beneficial effects on soil fertility. Boelcke et al. (1998) showed that soil humus content and cation exchange capacity in a 4- to 8-yr-old stand increased significantly, along with a slight increase in water retention. Clifton-Brown et al. (2007) also showed the potential of miscanthus to sequester 5.2 to $7.2 \mathrm{Mg} \mathrm{C} \mathrm{ha}^{-1}$ organic $\mathrm{C}$ in the soil over $15 \mathrm{yr}$ depending on harvest time. None of those soil fertility trials compared miscanthus to switchgrass.

In Spain, the production of miscanthus has been tested in Santiago, Caldas, and Rianxo (Galicia, northwestern Spain) (Bao et al., 1996) and in Alcala de Henares (Madrid, central Spain) (Christou et al., 2004). In Galicia, the crop was not viable in areas with permanent flooding such as Caldas (average biomass yield in the third year of $4 \mathrm{Mg} \mathrm{ha}^{-1}$ ) (Bao et al., 1996). In Santiago, yields averaged 5.1 and $13.6 \mathrm{Mg} \mathrm{ha}^{-1}$ in the second and third years, and in areas of maritime influence (Rianxo) 32 and $34 \mathrm{Mg} \mathrm{ha}^{-1}$ in the second and third years, respectively (Bao et al., 1996). In Alcala de Henares, Christou et al. (2004) tested miscanthus without irrigation, obtaining an average (first $3 \mathrm{yr}$ ) yield of $3.0 \mathrm{Mg} \mathrm{ha}^{-1}$, exhibiting severe yield limitation without supplemental water.

Trials on switchgrass have been conducted in diverse Spanish locations. In Alcala de Henares (Madrid), Christou et al. (2004) obtained average annual yields in winter harvests of $5.0 \mathrm{Mg} \mathrm{ha}^{-1}$ in the first 3 yr. In Candás (Asturias), Oliveira et al. (2012) recorded average annual yields (among six cultivars of switchgrass) of 13.4 $\mathrm{Mg} \mathrm{ha}^{-1}$ in autumn harvests of the first $2 \mathrm{yr}$ after planting. In Palma de Mallorca (Mediterranean Sea), Janer et al. (2016) obtained average yields of cultivar Alamo switchgrass of $7.5 \mathrm{Mg} \mathrm{ha}^{-1}$ in winter harvests in the first $2 \mathrm{yr}$ after planting. In areas of Atlantic and maritime influence, miscanthus generally had higher annual yields (32-34 $\mathrm{Mg} \mathrm{ha}^{-1}$ ) in Rianxo (Galicia) than switchgrass (13.4 $\mathrm{Mg} \mathrm{ha}^{-1}$, average of the first $2 \mathrm{yr}$ ) in Candás (Asturias). This generalization is not based on side-by-side comparisons.

The European Union (EU) Renewable Energy Directive established an overall policy for the production and promotion of renewable energy requiring at least $20 \%$ of its total energy from renewables by 2020 (Directive 2009/28/EC, 2009). Although Spain has an important potential (third greatest in Europe) of biomass resources (19 million $\mathrm{Gg}$ [kilotonnes] of oil equivalent; Netherlands Enterprise Agency, 2014), the technological developments in the field of biofuels and bioenergy are behind the targets mentioned in the Spanish Renewable Energies Plan 2011 to 2020 (IDAE, 2011). This includes a $20.8 \%$ share of renewables in final energy consumption $(20.8 \%$ being a national target; the EU target for Spain's renewables is 20\%).

The objectives of this paper are (i) to quantify changes in soil fertility of miscanthus and switchgrass over time, (ii) to compare the productivities of miscanthus and switchgrass in a side-by-side trial; and (iii) to evaluate the concentrations and removal of the macronutrients $\mathrm{N}, \mathrm{P}$, and $\mathrm{K}$ in the harvested biomass as affected by species, cultivar, and year in a humid environment in Asturias (northwestern Spain).

\section{MATERIALS AND METHODS}

\section{Crop Establishment}

One field trial comparing miscanthus (one clone from Sieverdingbeck-Agrar, Germany) and switchgrass (cultivars Cave-in-Rock, Alamo, and Kanlow) was established on an inceptisol Typic Dystrudept soil in 2011 in Candás $\left(43^{\circ} 35^{\prime} 03.95^{\prime \prime} \mathrm{N}\right.$, $5^{\circ} 46^{\prime} 56.32^{\prime \prime} \mathrm{W}$, elevation $80 \mathrm{~m}$, Asturias, Spain) under a temperate maritime climate. The study area (Candás, Asturias) is included in the Euro-Siberian ecoregion in the Atlantic-European province in northern Spain. Candás is further included in the phytogeographical Cantabrian-Atlantic subprovince (Díaz González and Fernández Prieto, 1994).

The field trial was planted in a randomized complete block design of four 3 by $8 \mathrm{~m}$ plots each of miscanthus and the three cultivars of switchgrass (16 plots total). Rhizomes of miscanthus were transplanted at a density of 1 plant $\mathrm{m}^{-2}$. Switchgrass seed was sown with an Earthway Precision Garden Seeder (model 1001-B, Earthway Products, Inc., Bristol, IN) with seed plate no. $1002-5$ at a seeding depth of 0.5 to $1 \mathrm{~cm}, 8$-cm spacing and rows $0.5 \mathrm{~m}$ apart, into a fine seedbed at the rate of $11 \mathrm{~kg} \mathrm{ha}^{-1}$ pure live seed on 26 Mar. 2011. To ensure even stand development, plots had sprinkler irrigation until switchgrass seedlings and miscanthus rhizomes started to emerge. Weeds were controlled in the establishment year by application of a postemergence herbicide mix of nicosulfuron $\{2$-[(4,6-dimethoxypyrimidine-2-ylcarbamoyl)sulfamoyl]-N,N-dimethylnicotinamide $\}$ ( $20 \mathrm{~g} \mathrm{ha}^{-1}$ a.i.), MCPA [(4-chloro-2-methylphenoxy)acetic acid] (265 $\mathrm{g} \mathrm{ha}^{-1}$ a.i.), 2,4-D [(2,4-dichlorophenoxy)acetic acid] (296 $\mathrm{g} \mathrm{ha}^{-1}$ a.i.), and dicamba (3,6-dichloro-2-methoxybenzoic acid) (100 $\mathrm{g} \mathrm{ha}^{-1}$ a.i.) applied after switchgrass had at least three to four leaves per plant.

The trial did not receive $\mathrm{N}$ fertilizer during the year of planting, and in the following years, the trial received $50 \mathrm{~kg} \mathrm{~N} \mathrm{ha}^{-1} \mathrm{yr}^{-1}$ at the beginning of each growing season (April).

\section{Soil Analyses}

Before trial establishment, a 2.54-cm diam. core was taken with a soil coring tube to 100-cm depth on March 2011 in two sites of the trial area. Each core was cut into segments of 0 - to 20-, 20 - to 40-, 40- to 60-, 60- to 80- and 80- to 100-cm depth increments.

Each year at the beginning of the growing season in the spring, soil samples were collected to a depth of $20 \mathrm{~cm}$ with a soil Dutch auger (Chemlabor, S.L., Llanera, Asturias, Spain) with a 20-cm cylinder length and $5-\mathrm{cm}$ interior diameter. Each soil sample was a mixed composite sample of three random cores per plot.

The samples were air-dried, crumbled, finely crushed and sieved with a 2-mm screen before analysis, in duplicate. Particlesize distribution was determined by the pipette method, and sodium hexametaphosphate and $\mathrm{Na}_{2} \mathrm{CO}_{3}$ were used to disperse 
the samples. The $\mathrm{pH}$ was measured in water with a glass electrode in a 1:2.5 suspension of soil to water, and electrical conductivity (EC) was measured in the same extract (diluted 1:5). Total organic $\mathrm{C}$ was determined at the Environmental Testing Unit of the Scientific-Technical Services of the University of Oviedo in Mieres, using a total organic C analyzer (SSM-5000A, Shimadzu, Tokyo, Japan).

Mineral (plant-available) $\mathrm{N}$ (ammonium $\mathrm{NH}_{4}{ }^{+}-\mathrm{N}$, and nitrate $\mathrm{NO}_{3}{ }^{-}-\mathrm{N}$ ) was extracted with the Spurway method (4 g of soil rinsed with $24 \mathrm{~mL}$ of water with three drops of acetic acid 1:4), followed with filtration of the extract. Ammonium $\mathrm{N}$ and $\mathrm{NO}_{3}{ }^{-}-\mathrm{N}$ were determined using ultra violet visible spectrophotometry (Lambda 900, PerkinElmer Inc., MA), based on the colorimetric methods with Nessler reagent for $\mathrm{NH}_{4}{ }^{+}$or brucine for $\mathrm{NO}_{3}{ }^{-}$. The determination of mineral $\mathrm{N}$ was performed at the Photoelectron Spectroscopy Unit of the ScientificTechnical Services of the University of Oviedo in Oviedo.

Extractable P was determined colorimetrically with Mehlich 3 reagent. Exchangeable cations $\left(\mathrm{K}^{+}, \mathrm{Ca}^{+2}, \mathrm{Mg}^{+2}\right.$, and $\mathrm{Na}^{+}$) were extracted with $1 \mathrm{M} \mathrm{NH}_{4} \mathrm{Cl}$, and exchangeable aluminum $\left(\mathrm{Al}^{+3}\right)$ extracted with $1 \mathrm{M} \mathrm{KCl}$, and determined by atomic absorption/emission spectrophotometry. The effective cation exchange capacity (ECEC) was calculated as the sum of the molar values of exchangeable cations and $\mathrm{Al}$.

\section{Biomass Yield, Nutrient Concentrations, and Nutrient Removal}

Aboveground biomass was sampled for four consecutive production years (2012-2015) to calculate yield. The entire trial was harvested after all plants in the plots had senesced, at the end of February or first days of March of the following calendar year. The outer $1 \mathrm{~m}$ of each plot was treated as guard rows, and the inner $6-\mathrm{m}^{2}$ area was cut with a duplex sicklebar mower (BCS 615 L Max, BCS Ibérica, Barcelona, Spain), of 1-m width to 10-cm stubble height.

The harvested plant material was weighed using a $100 \mathrm{~kg}$ maximum weighing capacity by 50 -g increments, digital dynamometer (MKC/N, Motorman, Barcelona, Spain). Biomass samples (200 g) were taken at each harvest and dried at $70^{\circ} \mathrm{C}$ for $48 \mathrm{~h}$ in an air circulation oven (Function Line, Heraeus, Dismed S.A., Asturias) to determine moisture content. Dried samples were ground to pass a 1-mm mesh screen ultra-centrifugal rotor mill (ZM 200, Retsch, Biometa, Asturias) before analysis, in duplicate.

Energy density was determined with a calorimetric bomb (IKA-Werke GmbH \& Co. KG, Langenselbold, Germany) using the adiabatic method according to the Spanish standard UNE 32006 in the Animal Nutrition Laboratory of the Regional Service for Agri-food Research and Development (SERIDA). Ash was analyzed with a muffle furnace (K114, Heraeus, Dismed S.A., Asturias) with incineration at $450^{\circ} \mathrm{C}$ during $12 \mathrm{~h}$.

Elemental analysis was determined with the a CHNS analyzer (Vario Macro, Elementar Analysensysteme GmbH, Germany) in the Thermal and Elemental Analysis Unit of the ScientificTechnical Services of the University of Oviedo in Oviedo. The concentration of $\mathrm{P}$ was determined by colorimetric analysis following combustion for $4 \mathrm{~h}$ in a muffle furnace at $450^{\circ} \mathrm{C}$, and dissolution of the ashes with $6 \mathrm{M} \mathrm{HCl}$. Analysis of $\mathrm{Ca}, \mathrm{Mg}$, and $\mathrm{K}$ was by atomic spectrophotometry in the same extract.

\section{Statistical Analyses}

Data were analyzed using a randomized complete block, splitplot in time design (Steel and Torrie, 1980) with four blocks, with the GLM procedure in SPSS 22.0 (IBM Corp. Released, 2013). For semantic convenience, we refer to all four crop entries as "cultivars." The whole-plot factor was the crop cultivar treatment, and the split-plot factor was the year of harvest. Cultivar was considered a fixed effect, whereas year and block were considered random effects. The interaction of block $\times$ cultivar $(\mathrm{df}=9)$ was used as the error term to test the cultivar effect. The interaction block $\times$ year $(\mathrm{df}=9)$ was used to test the year effect. The interaction block $\times$ cultivar $\times$ year $(\mathrm{df}=27)$ was the error term used to test the cultivar $\times$ year interaction. A split-plot in time design assumes that the dependence among observations is unchanging over time. If treatments are randomly assigned and are sufficiently separated in time, then this assumption will generally be valid (Quinn and Keough, 2002). Significant cultivar means were compared by the LSD protected Fischer's test at $\alpha=0.05$.

\section{RESULTS AND DISCUSSION Weather Conditions}

Long-term monthly averages of temperature and precipitation (Tables 1 and 2) indicate a typical humid, temperate, maritime climate, with generally moderate temperatures and adequate rainfall for dryland agriculture, with peak rainfall in autumn-winter and a minimum in summer. During the year of establishment (2011) and subsequent $4 \mathrm{yr}$ of biomass production, temperatures during the main growing season of May to September varied within a rather narrow range (Table 1). The main deviation was cooler-than-normal temperatures during May and June of 2013. The main periods of water deficit occurred during the principal growing periods of 2011 and 2012 and in mid- to late summer of 2013 (Table 2).

\section{Soil Analyses}

The properties of two deep soil cores extracted from the plot area before trial establishment (Table 3 ) revealed good similarity across the trial area and no clear limitations for switchgrass production. Site 1 had slightly more $\mathrm{C}$ and clay than Site 2 . Contents of $\mathrm{NH}_{4}-\mathrm{N}$ were high and of $\mathrm{NO}_{3}-\mathrm{N}$ were moderate, suggesting $\mathrm{N}$ availability would not be a serious limitation during establishment. Levels of Mehlich P were below $30 \mathrm{mg} \mathrm{P} \mathrm{kg}^{-1}$, suggesting that switchgrass may respond to $\mathrm{P}$ fertilization (Monterroso et al., 1999). The molar equivalents of exchangeable $\mathrm{K}, \mathrm{Ca}, \mathrm{Mg}$, $\mathrm{Na}$, and $\mathrm{Al}$ indicate the occupancy of those elements on cation exchange sites, from which ECEC was calculated. Responses to fertilizer elements such as $\mathrm{P}$ and $\mathrm{K}$ as predicted by soil test levels have not been elucidated for miscanthus and switchgrass in northern Spain; however, using guidelines by Horneck et al. (2011) for grasses in Oregon, the concentrations of exchangeable $\mathrm{K}$ appear to have been somewhat marginal, and could lead to deficiency if repeated harvesting of biomass occurred without $\mathrm{K}$ replenishment either from soil stocks or fertilization. Concentrations of $\mathrm{Na}$ and $\mathrm{Al}$ were low (Junta de Extremadura, 1992), indicating no limitations to switchgrass growth with respect to sodicity or Al toxicity. The ECEC tended to be slightly greater in Site 1, resulting mainly from generally higher levels of $\mathrm{Mg}, \mathrm{K}$, and $\mathrm{Na}$. The ECEC was in the normal range for loamy soils (Espinoza et al., 2006). 


\begin{tabular}{|c|c|c|c|c|c|c|}
\hline Month & 2011 & 2012 & 2013 & 2014 & 2015 & Long-term average $\ddagger$ \\
\hline January & 9.1 & 9.3 & 8.9 & 10.5 & 8.5 & 9.1 \\
\hline February & 9.9 & 7.4 & 8.5 & 10.1 & 8.5 & 9.3 \\
\hline March & 11.2 & 10.2 & 10.3 & 10.8 & 10.7 & 11.0 \\
\hline April & 14.1 & 10.8 & 11.4 & 13.7 & 13.4 & 12.3 \\
\hline May & 15.6 & 14.5 & 12.2 & 14.0 & 15.0 & 13.9 \\
\hline June & I7.1 & 17.3 & 15.5 & 17.8 & 17.4 & 17.5 \\
\hline July & 18.2 & 18.2 & 19.9 & 19.4 & 20.2 & 19.3 \\
\hline August & 19.4 & 20.3 & 19.5 & 19.5 & 19.7 & 19.8 \\
\hline September & 18.8 & 18.2 & 18.3 & 19.6 & I7.I & 18.0 \\
\hline October & 15.7 & 14.7 & 16.3 & 17.0 & 15.2 & 15.5 \\
\hline November & 12.9 & 10.7 & 11.9 & 12.8 & 13.3 & 11.7 \\
\hline December & 10.5 & 10.0 & 8.8 & 10.1 & 11.9 & 9.4 \\
\hline Average & 14.4 & 13.5 & 13.5 & 14.6 & 14.3 & 13.9 \\
\hline
\end{tabular}

† Data were obtained from the weather station closest to the study site, in Gijón ( $43^{\circ} 32^{\prime} 17^{\prime \prime} \mathrm{N}, 5^{\circ} 37^{\prime} 26^{\prime \prime} \mathrm{W}$, elevation $30 \mathrm{~m}$ a.s.I.).

$\ddagger$ Long-term averages were calculated over the period of 1995 to 2015. Source: www.meteogijon.es.

Table 2. Monthly and total precipitation from $201 \mathrm{I}$ to 2015 and long-term average precipitation at Candás, Asturias, Spain.†

\begin{tabular}{|c|c|c|c|c|c|c|}
\hline Month & 2011 & 2012 & 2013 & 2014 & 2015 & Long-term average $\ddagger$ \\
\hline January & 9.8 & 3.2 & 22.8 & 12.1 & 15.4 & 10.9 \\
\hline February & 4.7 & 5.6 & 21.9 & 9.5 & 16.2 & 8.8 \\
\hline March & 6.8 & 2.1 & 22.4 & II.I & 11.2 & 8.9 \\
\hline April & 2.1 & 15.8 & 17.8 & 5.5 & 6.1 & 9.2 \\
\hline May & 3.0 & 1.6 & 12.6 & 6.0 & 3.3 & 6.4 \\
\hline June & 2.1 & 6.6 & 6.5 & 1.0 & 5.2 & 4.9 \\
\hline July & 4.4 & I.8 & 0.9 & 4.8 & 3.4 & 4.5 \\
\hline August & 2.6 & 1.7 & 3.0 & 4.3 & 8.6 & 5.6 \\
\hline September & 2.5 & I.7 & 3.8 & 6.4 & 6.0 & 6.5 \\
\hline October & 3.3 & 9.6 & 4.6 & 5.0 & 3.1 & 9.4 \\
\hline November & 5.6 & 12.6 & 15.9 & 9.4 & 7.3 & I4.1 \\
\hline December & 9.3 & 8.6 & 7.1 & 12.0 & 2.1 & II.I \\
\hline Sum & 56.2 & 70.9 & 139.3 & 87.1 & 87.9 & 100.3 \\
\hline
\end{tabular}

† Data were obtained from the weather station closest to the study site, in Gijón ( $43^{\circ} 32^{\prime} 17^{\prime \prime} \mathrm{N}, 5^{\circ} 37^{\prime} 26^{\prime \prime} \mathrm{W}$, elevation $30 \mathrm{~m}$ a.s.l.).

$\ddagger$ Long-term averages were calculated over the period of 1995 to 2015 . Source: www.meteogijon.es.

Table 3. Soil chemical and physical properties at the beginning of the trial (20II) in two sites of the Candás whole plot (Asturias, Spain).

\begin{tabular}{|c|c|c|c|c|c|c|c|c|c|c|}
\hline \multirow[b]{2}{*}{ Property } & \multicolumn{5}{|c|}{ Site I } & \multicolumn{5}{|c|}{ Site 2} \\
\hline & $0-20$ & $20-40$ & $40-60$ & $60-80$ & $80-100$ & $0-20$ & $20-40$ & $40-60$ & $60-80$ & $80-100$ \\
\hline $\mathrm{pH} \mathrm{I:2.5}$ & 6.3 & 6.4 & 6.6 & 6.7 & 6.8 & 6.2 & 6.3 & 6.4 & 6.5 & 6.7 \\
\hline $\mathrm{EC} \dagger, \mathrm{dS} \mathrm{m}^{-1}$ & 0.08 & 0.07 & 0.06 & 0.04 & 0.04 & 0.07 & 0.06 & 0.05 & 0.04 & 0.03 \\
\hline C, $\mathrm{g} \mathrm{kg}^{-1}$ & 32.2 & 30.0 & 28.1 & 23.0 & 10.0 & 31.8 & 29.3 & 21.8 & 9.2 & 6.0 \\
\hline $\mathrm{NH}_{4}-\mathrm{N}, \mathrm{mg} \mathrm{kg}^{-\mathrm{I}}$ & 35.6 & 33.2 & 31.1 & 25.4 & II.I & 35.1 & 32.4 & 24.1 & 10.2 & 6.6 \\
\hline $\mathrm{NO}_{3}-\mathrm{N}, \mathrm{mg} \mathrm{kg}^{-1}$ & 9.9 & 9.3 & 8.7 & 7.1 & 3.1 & 9.8 & 9.0 & 6.7 & 2.8 & 1.8 \\
\hline $\mathrm{P}, \mathrm{mg} \mathrm{kg}^{-\mathrm{I}}$ & 25.0 & 24.0 & 22.0 & 21.0 & 20.0 & 24.0 & 23.0 & 22.0 & 21.0 & 19.0 \\
\hline $\mathrm{Ca}, \mathrm{cmol}_{\mathrm{c}} \mathrm{kg}^{-1}$ & 8.70 & 8.50 & 8.30 & 8.20 & 8.00 & 8.60 & 8.50 & 8.30 & 8.10 & 7.80 \\
\hline $\mathrm{Mg}, \mathrm{cmol}^{\mathrm{c}} \mathrm{kg}^{-1}$ & 1.38 & 1.28 & 1.19 & 1.08 & 1.00 & 1.19 & 1.17 & 1.09 & 1.05 & 1.10 \\
\hline $\mathrm{K}, \mathrm{cmol}_{\mathrm{c}} \mathrm{kg}^{-\mathrm{I}}$ & 0.37 & 0.36 & 0.34 & 0.32 & 0.29 & 0.29 & 0.28 & 0.26 & 0.24 & 0.21 \\
\hline $\mathrm{Na}, \mathrm{cmol}^{\mathrm{kg}^{-1}}$ & 0.42 & 0.45 & 0.48 & 0.50 & 0.52 & 0.37 & 0.40 & 0.43 & 0.46 & 0.49 \\
\hline $\mathrm{Al}, \mathrm{cmol}_{\mathrm{c}} \mathrm{kg}^{-1}$ & 2.18 & 2.00 & 1.80 & 1.60 & 0.80 & 2.25 & 2.00 & 1.70 & 1.50 & 1.00 \\
\hline ECEC, $\mathrm{cmol}_{\mathrm{c}} \mathrm{kg}^{-1}$ & 13.05 & 12.59 & 12.11 & 11.70 & $10.6 \mid$ & 12.70 & 124 & 11.78 & 11.35 & 10.60 \\
\hline Bulk density, $\mathrm{Mg} \mathrm{m}^{-3}$ & 1.43 & 1.42 & 1.50 & $|.5|$ & $|.5|$ & 1.42 & 1.55 & 1.56 & 1.57 & 1.58 \\
\hline Sand, $\mathrm{g} \mathrm{kg}^{-\mathrm{i}}$ & 708 & 684 & 757 & 705 & 705 & 639 & 789 & 765 & 772 & 754 \\
\hline Clay, $\mathrm{g} \mathrm{kg}^{-1}$ & 252 & 260 & 170 & 159 & 152 & 248 & 127 & 115 & 108 & 97 \\
\hline Silt, $\mathrm{g} \mathrm{kg}^{-1}$ & 40 & 56 & 73 & 136 & 143 & 113 & 84 & 119 & 120 & 149 \\
\hline Textural class & $\begin{array}{l}\text { Sandy } \\
\text { clay loam }\end{array}$ & $\begin{array}{l}\text { Sandy } \\
\text { clay loam }\end{array}$ & $\begin{array}{l}\text { Sandy } \\
\text { loam }\end{array}$ & $\begin{array}{l}\text { Sandy } \\
\text { loam }\end{array}$ & $\begin{array}{l}\text { Sandy } \\
\text { loam }\end{array}$ & $\begin{array}{l}\text { Sandy } \\
\text { clay loam }\end{array}$ & $\begin{array}{l}\text { Sandy } \\
\text { loam }\end{array}$ & $\begin{array}{l}\text { Sandy } \\
\text { loam }\end{array}$ & $\begin{array}{l}\text { Sandy } \\
\text { loam }\end{array}$ & $\begin{array}{l}\text { Sandy } \\
\text { loam }\end{array}$ \\
\hline
\end{tabular}

$\dagger \mathrm{EC}=$ electrical conductivity; $\mathrm{ECEC}=$ effective cation exchange capacity. 
Soil variables decreased with increasing soil depth, except $\mathrm{pH}$, exchangeable $\mathrm{Na}$, and bulk density.

Stands were established in spring of 2011, but growth was slow and sparse, and stands were weedy; therefore no biomass data were collected. Annual sampling of soil chemical characteristics in the surface 0 to $20 \mathrm{~cm}$ showed that cultivar had no significant $(P>0.05)$ main effect on $\mathrm{pH}$ and EC (Table 4$)$. Soil $\mathrm{pH}$ increased $(P<0.001)$ from 6.48 to 6.75 , and EC increased from 0.087 to $0.148 \mathrm{dS} \mathrm{m} \mathrm{m}^{-1}$ from 2012 to 2015 , both staying within favorable ranges for plant growth.

Soil C concentration was greatest in Kanlow and least in Cave-in-Rock $(P<0.001)$ (Table 4$)$, but all cultivars increased in soil $C$ at the same rate from 2012 to $2015(P>0.05$ for the interaction, data not shown). The soil C concentration mean among cultivars increased from $32.8 \mathrm{~g} \mathrm{~kg}^{-1}$ after the 2012 biomass harvest to $35.8 \mathrm{~g} \mathrm{~kg}^{-1}$ at the end of the 2015 harvest, for an annual change of $1.0 \mathrm{~g} \mathrm{~kg}^{-1}$. Using the pre-establishment mean bulk density of 1.425 (Table 3), this rate of change constituted an annual $\mathrm{C}$ sequestration rate of $2850 \mathrm{~kg} \mathrm{ha}^{-1}$. Estimates of annual soil $\mathrm{C}$ sequestration by energy crops such as switchgrass range from 500 to $2900 \mathrm{~kg} \mathrm{ha}^{-1}$ (Al-Kaisi et al., 2005; Ma et al., 2000; Sanderson et al., 1999). Kahle et al. (2002) observed annual C sequestration of $1220 \mathrm{~kg} \mathrm{ha}^{-1}$ in miscanthus plots ranging from 4- to 10 -yr old, in northeastern Germany. Our results are at the upper part of the reported ranges.

Soil $\mathrm{NH}_{4}-\mathrm{N}$ was greatest with Kanlow and least with Cavein-Rock $(P<0.001$; Table 4$)$, and levels increased in all cultivars in sequential years (yearly means from $32.4-36.7 \mathrm{mg} \mathrm{kg}^{-1}$ ). Even though the cultivar rankings were consistent across years, the cultivar $\times$ year interaction was significant $(P<0.001)$, resulting from miscanthus increasing at a slower rate than the switchgrass cultivars. The sum of $\mathrm{NH}_{4}-\mathrm{N}$ and $\mathrm{NO}_{3}-\mathrm{N}$ (total plant-available $\mathrm{N}$ ) increased from 2012 to 2015 by $4.6 \mathrm{mg} \mathrm{kg}^{-1}$ (averaged over all cultivars, of which $\mathrm{NH}_{4}-\mathrm{N}$ accounted for $4.3 \mathrm{mg} \mathrm{kg}^{-1}$ ), which was small in relation to the pre-establishment pool of $45.2 \mathrm{mg} \mathrm{kg}^{-1}$ at 0 - to 20-cm depth (Table 3, average of two sites). This increase in plant-available $\mathrm{N}$ signaled that multiple-year harvests of biomass with an annual fertilization rate of $50 \mathrm{~kg} \mathrm{ha}^{-1}$ of $\mathrm{N}$ did not result in a drawdown of the readily available $\mathrm{N}$ pool. Although not measured, the large increase in $\mathrm{C}$ stock would have also resulted in sequestration of $\mathrm{N}$ in the total soil $\mathrm{N}$ pool, which is typical in perennial grassland soils (Whitehead, 1995).

Extractable soil $P$ did not differ among cultivars (Table 4), but steadily declined $(P<0.001)$ from $19.1 \mathrm{mg} \mathrm{kg}^{-1}$ in 2012 to $14.2 \mathrm{mg} \mathrm{kg}^{-1}$ after the 2015 biomass harvest (data not shown), suggesting that repeated harvests would eventually lead to $\mathrm{P}$ deficiency (INIA, 2009). Exchangeable K, Ca, Mg, Na, Al, and ECEC showed no significant cultivar effects (Table 4). As with soil $\mathrm{P}$, yearly values of exchangeable elements followed negative trends in all except $\mathrm{Na}$, which increased over years from 0.30 to $0.40 \mathrm{cmol}_{\mathrm{c}} \mathrm{kg}^{-1}$. Cultivar $\times$ year interactions for Ca and ECEC revealed no patterns of agronomic significance despite their statistical significance (data not shown).

\section{Biomass Yield, Nutrient Concentrations, and Nutrient Removal}

Biomass moisture content at harvest varied with cultivar $(P<$ 0.001) with miscanthus and Cave-in-Rock showing lowest moisture and Alamo showing highest (Table 5), with a consistent ranking among years. Moisture content showed no significant changes across years $(P>0.05$; data not shown). The high moisture content of Alamo was unexpected since harvests were made in late winter well after complete biomass senescence, with no visible green tissue. Winters are cool and humid in the Asturias region of Spain, which would favor high moisture retention in biomass. Alamo and Kanlow are lowland types of switchgrass and mature later than upland Cave-in-Rock (Kiniry et al., 2013; McLaughlin and Kszos, 2005), so Alamo possibly senesced later than Cave-in-Rock and did not dry down before winter. Delayed dry-down of a biomass crop is disadvantageous because more time, mechanical handling, and possibly energy input would be required to prepare the biomass for transport and storage (Lewandowski and Kicherer, 1997).

Biomass yield was greatest in miscanthus and least in Cave-inRock $(P<0.001$; Table 5$)$. The highly significant cultivar $\times$ year interaction indicated similarly low biomass yields of the cultivars in the first full year of production (2012) followed by a large disparity in yields in later years (Fig. 1a). Peak yields or leveledoff yields were obtained in 2014. The trends showed the typical

Table 4. Post-establishment soil properties $(0-20 \mathrm{~cm})$ of four biomass crop cultivars, means of 4 yr $(2012-2015)$ and four replications.

\begin{tabular}{|c|c|c|c|c|c|c|c|}
\hline Property & Miscanthus & Cave-in-Rock & Alamo & Kanlow & Cultivar effect & Year effect & Cultivar $\times$ year \\
\hline & & & & & & Significance & +2 \\
\hline $\mathrm{pH}$ & 6.40 & 6.63 & 6.62 & 6.57 & nst & $* * *$ & ns \\
\hline $\mathrm{EC} \neq, \mathrm{dS} \mathrm{m}^{-1}$ & 0.101 & 0.106 & 0.102 & 0.100 & ns & $* * *$ & ns \\
\hline $\mathrm{C}, \mathrm{g} \mathrm{kg}^{-1}$ & $32.9 c$ & $31.3 d$ & $35.7 b$ & $36.9 a$ & $* * *$ & $* * *$ & ns \\
\hline $\mathrm{NH}_{4}-\mathrm{N}, \mathrm{mg} \mathrm{kg}^{-\mathrm{I}}$ & $32.3 c$ & $31.3 d$ & $35.9 b$ & $37.3 a$ & $* * *$ & $* * *$ & $* * *$ \\
\hline $\mathrm{NO}_{3}-\mathrm{N}, \mathrm{mg} \mathrm{kg}^{-\mathrm{I}}$ & $12.2 \mathrm{c}$ & $11.3 \mathrm{~d}$ & $12.8 \mathrm{~b}$ & $13.4 \mathrm{a}$ & $* * *$ & $* * *$ & $* * *$ \\
\hline $\mathrm{P}, \mathrm{mg} \mathrm{kg}^{-1}$ & I7. & 16.8 & 17.2 & 16.7 & ns & $* * *$ & ns \\
\hline $\mathrm{K}, \mathrm{cmol}_{\mathrm{c}} \mathrm{kg}^{-\mathrm{I}}$ & 0.20 & 0.19 & 0.20 & 0.20 & ns & $* * *$ & ns \\
\hline $\mathrm{Ca}, \mathrm{cmol}_{\mathrm{c}} \mathrm{kg}^{-\mathrm{l}}$ & 6.81 & 6.60 & 6.87 & 6.83 & ns & $* * *$ & $* *$ \\
\hline $\mathrm{Mg}, \mathrm{cmol}_{\mathrm{c}} \mathrm{kg}^{-\mathrm{I}}$ & 0.91 & 0.91 & 0.89 & 0.93 & ns & $* *$ & ns \\
\hline $\mathrm{Na}, \mathrm{cmol}_{\mathrm{c}} \mathrm{kg}^{-\mathrm{I}}$ & 0.33 & 0.33 & 0.32 & 0.33 & ns & $* * *$ & ns \\
\hline $\mathrm{Al}, \mathrm{cmol}_{\mathrm{c}} \mathrm{kg}^{-\mathrm{I}}$ & 1.55 & 1.50 & 1.50 & 1.49 & ns & $* * *$ & ns \\
\hline ECEC, $\mathrm{cmol}_{\mathrm{c}} \mathrm{kg}^{-\mathrm{I}}$ & 9.79 & 9.52 & 9.78 & 9.78 & ns & $* * *$ & $* *$ \\
\hline
\end{tabular}

** Significant at the 0.01 probability level.

*** Significant at the 0.001 probability level.

$\dagger \mathrm{ns}$, nonsignificant at the 0.05 probability level.

$\ddagger \mathrm{EC}=$ electrical conductivity; $\mathrm{ECEC}=$ effective cation exchange capacity. 
Table 5. Post-establishment moisture content (wet basis), biomass yield, height, energy density, concentrations of ash and macro-elements, and removal of macro-elements of four biomass crop cultivars, means of $4 \mathrm{yr}$ (2012 to 2015) and four replications.

\begin{tabular}{|c|c|c|c|c|c|c|c|}
\hline Variable & Miscanthus & Cave-in-Rock & Alamo & Kanlow & Cultivar effect $\dagger$ & Year effect $\dagger$ & Cultivar $\times$ year \\
\hline & & & & & \multicolumn{3}{|c|}{$\longrightarrow$ Significance $\longrightarrow$} \\
\hline Moisture, \% & $22.3 c$ & $20.1 \mathrm{c}$ & $46.2 \mathrm{a}$ & $31.8 b$ & $* * *$ & nst & ns \\
\hline Yield, Mg ha-I & $17.6 \mathrm{a}$ & 7.7c & $13.0 \mathrm{~b}$ & $13.3 \mathrm{~b}$ & $* * *$ & $* * *$ & $* * *$ \\
\hline Height, cm & $238 a$ & $181 \mathrm{c}$ & $200 b$ & $203 b$ & $* * *$ & $* * *$ & $* * *$ \\
\hline $\begin{array}{l}\text { Energy } \\
\text { density, MJ kg-1 }\end{array}$ & $17.2 b$ & $17.4 \mathrm{a}$ & $17.2 b$ & $17.4 \mathrm{a}$ & $* * *$ & $* * *$ & $* * *$ \\
\hline Ash conc., $\mathrm{mg} \mathrm{kg}^{-1}$ & $42.9 b$ & $43.7 \mathrm{ab}$ & $45.1 \mathrm{a}$ & $43.3 b$ & $*$ & $* * *$ & $* * *$ \\
\hline $\mathrm{N}$ concentration, $\mathrm{g} \mathrm{kg}^{-1}$ & $3.4 d$ & $4.1 \mathrm{c}$ & $6.3 a$ & $4.7 b$ & $* * *$ & $* * *$ & $* * *$ \\
\hline $\mathrm{P}$ concentration, $\mathrm{g} \mathrm{kg}^{-1}$ & $0.3 c$ & $0.4 b$ & $0.7 \mathrm{a}$ & $0.6 a$ & $* * *$ & $* * *$ & ns \\
\hline $\mathrm{K}$ concentration, $\mathrm{g} \mathrm{kg}^{-1}$ & $1.4 \mathrm{c}$ & $1.3 c$ & $2.0 \mathrm{~b}$ & $2.5 \mathrm{a}$ & $* * *$ & $* * *$ & $* * *$ \\
\hline$C$ concentration, $\mathrm{g} \mathrm{kg}^{-1}$ & 454 & 456 & 448 & 454 & ns & $* * *$ & $* *$ \\
\hline $\mathrm{N}$ removal, $\mathrm{kg} \mathrm{ha}^{-1}$ & $46.4 c$ & $24.7 d$ & $63.4 \mathrm{a}$ & $56.3 b$ & $* * *$ & $* * *$ & $* * *$ \\
\hline P removal, kg ha ${ }^{-1}$ & $3.9 b$ & $2.9 c$ & $7.3 a$ & $7.3 a$ & $* * *$ & $* * *$ & $* * *$ \\
\hline $\mathrm{K}$ removal, kg ha ${ }^{-1}$ & $23.0 \mathrm{~b}$ & $11.0 \mathrm{c}$ & $24.3 b$ & $36.0 \mathrm{a}$ & $* * *$ & $* * *$ & $* * *$ \\
\hline C removal, $\mathrm{kg} \mathrm{ha}^{-1}$ & $8216 a$ & $3562 c$ & $5863 b$ & $6110 b$ & $* * *$ & $* * *$ & $* * *$ \\
\hline
\end{tabular}

* Significant at the 0.05 probability level.

** Significant at the 0.01 probability level.

*** Significant at the 0.001 probability level.

$\dagger \mathrm{ns}$, nonsignificant at the 0.05 probability level.

process of stand development of perennial grasses used for biomass in that the first year is characterized by relatively sparse tillering and short stature (Alexopoulou et al., 2008). As crown size and plant height increase (Fig. 1b) during the first two full production years, biomass yields increase. The numbers next to the data points in Fig. 1a are the percentage yields in relation to the respective 2014 yields within the same cultivar. McLaughlin and Kszos (2005) generalized that switchgrass attains 33\% of its peak (by third year) yield in the first year and 66\% in the second

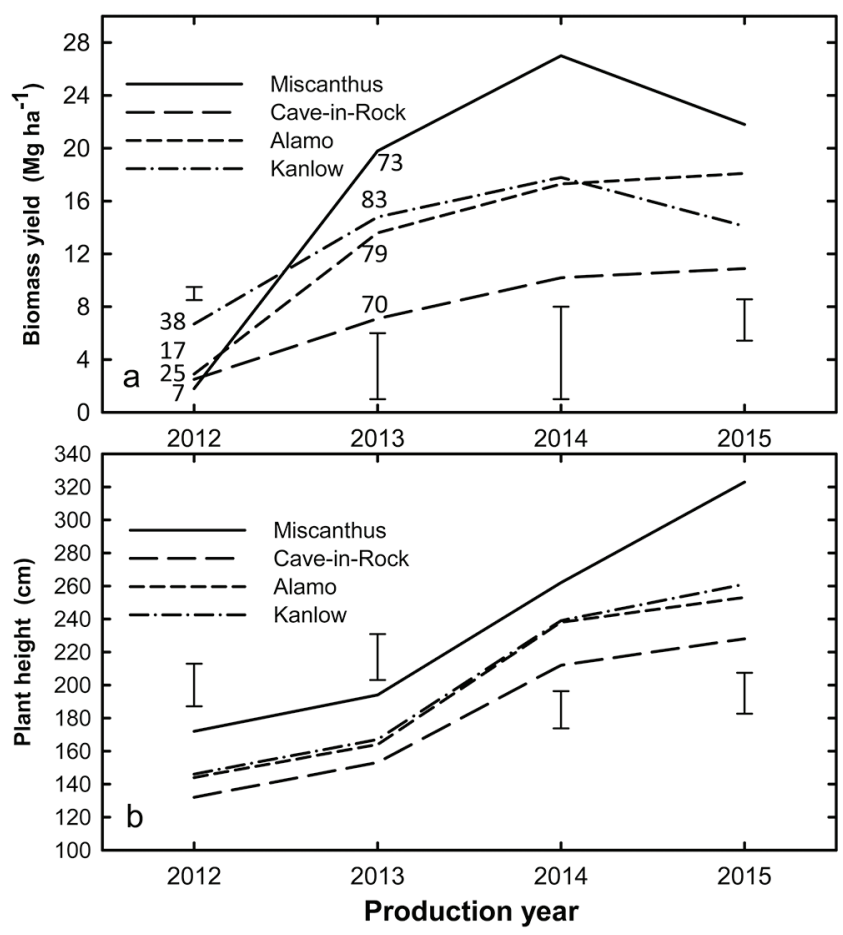

Fig. I. Trends in (a) biomass yield and (b) plant canopy height over $4 \mathrm{yr}$ of miscanthus and three cultivars of switchgrass. Numbers by biomass yield points indicate percentage of 2014 yield. Bars indicate LSD 0.05 for comparing cultivars within years. year. The mean percentages of 2014 yields for the three switchgrass cultivars in the present trial were 27 and $77 \%$ in 2012 and 2013, respectively. Elbersen et al. (2001a) and Alexopoulou et al. (2008) also reported large increases in biomass yield during the first $3 \mathrm{yr}$ of production in northern Europe and Mediterranean Europe, respectively. The low percentages of aboveground biomass yield in the first year are likely due to preferential allocation of photosynthate to roots and crown/rhizomes (Karp and Shield, 2008). Miscanthus clearly expressed higher yield potential than switchgrass over the latter 3 yr of this trial; however, longer duration is needed to ascertain the sustainability of that advantage. The yield advantage of miscanthus over switchgrass (mean of four cultivars including those tested in this paper) was also reported by Lasorella et al. (2011) with 14.9 vs. $11.9 \mathrm{Mg}$ $\mathrm{ha}^{-1}$, respectively, over $6 \mathrm{yr}$.

Plant height was greatest in miscanthus and least in Cave-inRock switchgrass (Table 5). This is consistent with other reports of these biomass crops in that Cave-in-Rock is an upland type selected from a natural population in Illinois, United States, and is typically earlier flowering and shorter in mature height than the lowland types from the southern plains of the United States, such as Alamo and Kanlow (Kiniry et al., 2013). The height superiority of miscanthus was expressed in all years (Fig. 1b), especially in the final trial year $(P<0.001)$. The superior height of miscanthus likely contributed to its higher yields in 2013 to 2015. The especially great disparity in biomass yield and height between miscanthus and Cave-in-Rock switchgrass was also noted by Heaton et al. (2008) and Arundale et al. (2014).

Energy density was greatest in Cave-in-Rock and Kanlow, when averaged over years (Table 5), and this difference was most pronounced in 2012 (significant cultivar $\times$ year interaction, $P<0.001$ ). Energy density was lowest in $2012\left(16.6 \mathrm{MJ} \mathrm{kg}^{-1}\right)$ and averaged $17.5 \mathrm{MJ} \mathrm{kg}^{-1}$ in the latter 3 yr. Energy density was lowest in the first full production year probably because stems, being relatively short in 2012, contributed a lesser proportion of mass to the total biomass than leaves (leaf-stem separation was not performed) compared 
with the latter years, and switchgrass stems tend to be more concentrated in lignin than are leaves (Mann et al., 2009).

Ash concentration varied slightly among cultivars $(P=0.029$, Table 5$)$, but was substantially lower in 2014 $\left(28.6 \mathrm{~g} \mathrm{~kg}^{-1}\right)$ than in the other $3 \mathrm{yr}$ (mean of $48.8 \mathrm{~g} \mathrm{~kg}^{-1}$ with no difference among those years). The reason for the anomaly in 2014 is unknown, and was not caused by depressions in concentrations $\mathrm{Ca}, \mathrm{K}$, or $\mathrm{Mg}$ (data not shown).

Biomass concentrations of $\mathrm{N}$ and $\mathrm{P}$ were consistently greatest in Alamo and lowest in miscanthus (Table 5), which agrees with results in two locations in the Netherlands (Elbersen et al., 2001b). Yearly means of $\mathrm{N}$ concentration exhibited a decline and leveling off over time $\left(6.3,4.3,2.9\right.$, and $2.9 \mathrm{~g} \mathrm{~kg}^{-1}$ for 2012 through 2015, respectively). Mean concentrations of P fluctuated over time, showing $0.9,0.2,0.6$, and $0.3 \mathrm{~g} \mathrm{~kg}^{-1}$ in sequential years. Concentrations of $\mathrm{K}$ were greatest in Kanlow (Table 5) and varied over the years in a non-progressive pattern, ranging from $1.4 \mathrm{~g} \mathrm{~kg}^{-1}$ in 2013 to $2.4 \mathrm{~g} \mathrm{~kg}^{-1}$ in 2014. Carbon concentration did not vary by cultivar (Table 5), but was lowest in 2012 and $2015\left(440 \mathrm{~g} \mathrm{~kg}^{-1}\right)$ and greatest in 2013 and $2014\left(475 \mathrm{~g} \mathrm{~kg}^{-1}\right)$ $(P<0.001)$.

Concentrations of macronutrients in the biomass were used to calculate their removal in the harvested biomass. Cultivars exhibited large differences in mean removal of $\mathrm{N}, \mathrm{P}$, and $\mathrm{K}$, with Alamo and Kanlow generally containing the most harvested N, $\mathrm{P}$, and $\mathrm{K}$ and Cave-in-Rock the lowest (Table 5). Cultivar $\times$ year interactions illustrated some re-rankings of cultivars according to the years (Fig. 2). The most consistent trends were that $\mathrm{N}$ removal in Cave-in-Rock was lowest in the latter 3 yr (Fig. 2a), and $\mathrm{P}$ and $\mathrm{K}$ removals peaked in 2014 in all cultivars (Fig. $2 \mathrm{~b}$ and 2c) in agreement with the high biomass yields observed (Fig. 1a) and their high concentrations of $\mathrm{P}$ and $\mathrm{K}$ in that year (data not shown). Biomass yield generally leveled off or declined in 2015 (Fig. 1a), which corresponded to a leveling off or decline in $\mathrm{P}$ and $\mathrm{K}$ concentrations (data not shown) and removal in 2015 (Fig. 2b and $2 \mathrm{c}$ ). This trend supports evidence that the observed decline in soil $\mathrm{P}$ and $\mathrm{K}$ over time may have contributed to the yield decline of miscanthus and Kanlow in 2015 despite the favorable rainfall and temperature conditions. The superior biomass yields of miscanthus in the latter $3 \mathrm{yr}$ contrast with its intermediate ranking among the four cultivars in macronutrient removal. This is explained by the relatively low concentrations of $\mathrm{N}, \mathrm{P}$, and $\mathrm{K}$ in the harvested biomass (Table 5).

Perennial herbaceous biomass crops such as miscanthus and switchgrass require minimal $\mathrm{N}$ fertilizer (Elbersen et al., 2001b) thanks to a combination of (i) high efficiency of converting $\mathrm{N}$ to growth, typical of C4 grasses (Parrish and Fike, 2005), and (ii) remobilization of nutrient reserves from crown organs, if harvest is delayed past autumn senescence (Adler et al., 2006; Sanderson et al., 2007). Continuous harvesting and removal of biomass from agricultural systems without nutrient replacement has the potential to mine soil of nutrients and affect long-term productivity of feedstocks (Fixen, 2007). Many regions where these crops show great promise for high biomass yields, such as the current site reported herein, do not yet have fertilizer recommendations defined because yield responses to fertilizers have not been calibrated to soil test values. Our soil and biomass data provide a basis for designing future trials in temperate Spain for fertilizer responses of the major macronutrients. For long-lived perennial grasses, the design of such trials begs the question of how many years are required to accommodate the facts that full stand development takes around $3 \mathrm{yr}$, interannual variation in weather affects yield and therefore nutrient removal, and the harvest frequency and timing (pre- vs. post-senescence) can greatly affect the crop nutrient requirement in an effort to balance uptake and removal rates. Our results suggest that $5 \mathrm{yr}$ (including the establishment year) should be a minimum duration to capture both the stand development and weather variation.

Quality of plant biomass for biofuels depends on whether conversion systems use biochemical, thermochemical, or direct combustion processes (Sanderson et al., 2007). For direct combustion and thermochemical conversion systems, reduced concentrations of alkali minerals (especially K) are desirable (van den Berg and de Visser, 2001). Harvesting at later maturity stages reduces mineral concentrations because of leaf droppage and leaching (El-Nashaar et al., 2009) and increases lignin concentration of biomass (Adler et al., 2006), both of which contribute to higher thermal energy density. Delayed harvest incurs a trade-off with biomass yield (Sanderson et al., 1999), therefore bioenergy planners must perform a whole-system analysis of logistics and economics to identify the optimum harvest window.
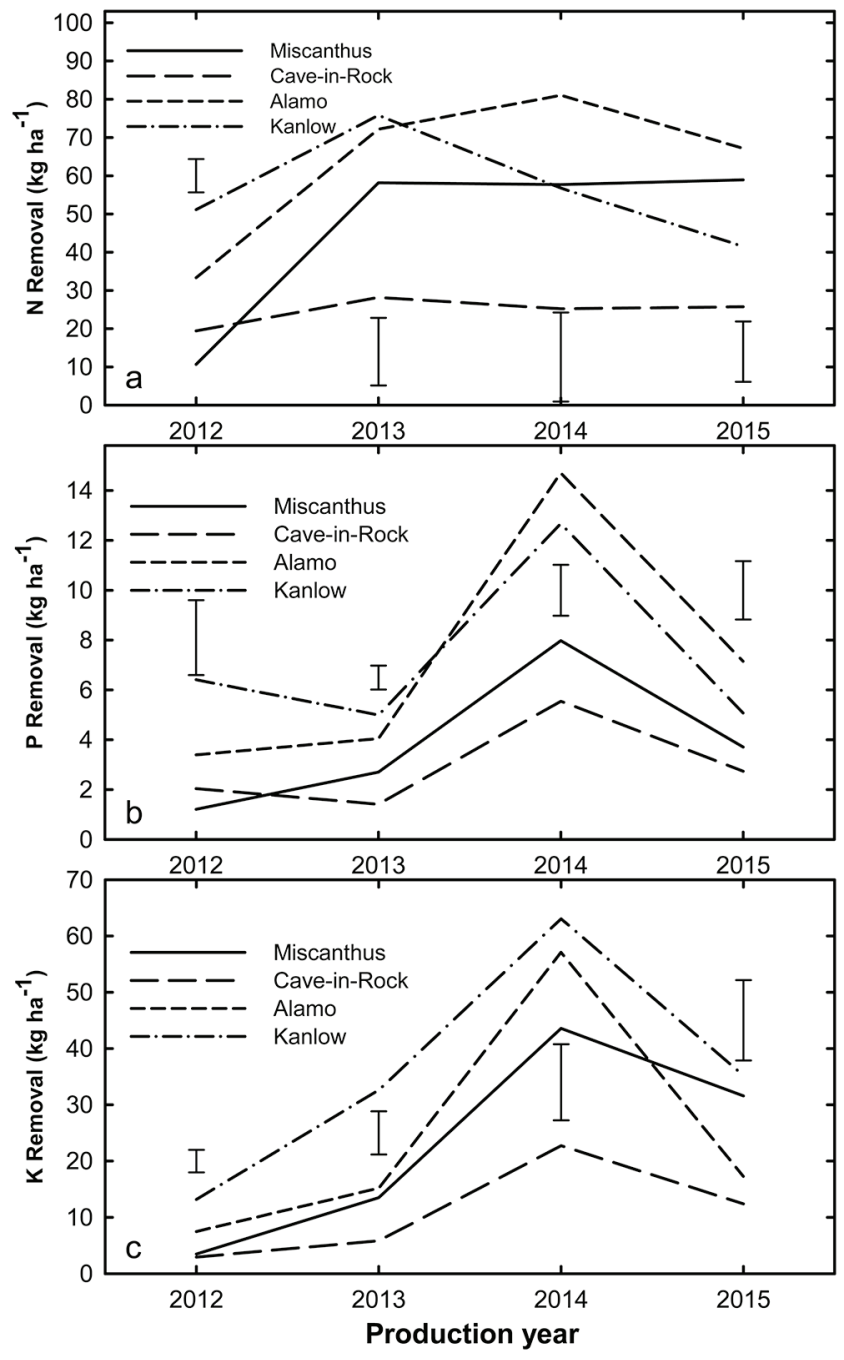

Fig. 2. Trends in crop harvest removal of (a) N, (b) P, and (c) K over $4 \mathrm{yr}$ of miscanthus and three cultivars of switchgrass. Bars indicate LSD 0.05 for comparing cultivars within years. 


\section{CONCLUSIONS}

Miscanthus had very high biomass yield, which together with its relatively low macronutrient concentrations and intermediate removal rates, would suggest this species as a preferred biomass crop in the Atlantic maritime region of Spain. The lowland switchgrass cultivars, Alamo and Kanlow, produced more biomass than the upland Cave-in-Rock, but also removed more macronutrients than Cave-in-Rock, suggesting a greater long-term fertilizer requirement. The higher cost and slower establishment of miscanthus over switchgrass (Heaton et al., 2008) would have to be part of the economic decision on which crop to grow. A longer-term study is required before drawing conclusions on soil $\mathrm{C}$ sequestration, but in this short-term sampling, substantial amounts of $\mathrm{C}$ were sequestered and at similar annual rates among the crops. The significant drop in soil-test $\mathrm{P}$ and $\mathrm{P}$ removal by the final year indicate that $\mathrm{P}$ was the macronutrient most likely to become deficient after repeated harvests in this environment.

\section{ACKNOWLEDGMENTS}

This research was partially supported by Contract CN-12-018 of the Oviedo University and the company Calfensa Proyectos S.L. (LugoGalicia). The authors are grateful to the owner of the Casero farm in Candás (Asturias) for allowing this long-term study.

\section{REFERENCES}

Adler, P.R., M.A. Sanderson, A.A. Boateng, P.J. Weimer, and H.G. Jung. 2006. Biomass yield and biofuel quality of switchgrass harvested in fall or spring. Agron. J. 98:1518-1525. doi:10.2134/agronj2005.0351

Alexopoulou, E., N. Sharma, Y. Papatheohari, M. Christou, I. Piscioneri, and V. Pigniatelli. 2008. Biomass yields for upland and lowland switchgrass varieties grown in the Mediterranean region. Biomass Bioenergy 32:926-933. doi:10.1016/j.biombioe.2008.01.015

Al-Kaisi, M.M., X. Yin, and M.A. Licht. 2005. Soil carbon and nitrogen changes as affected by tillage system and crop biomass in a corn-soybean rotation. Appl. Soil Ecol. 30:174-191. doi:10.1016/j. apsoil.2005.02.014

Aravindhakshan, S.C., F.M. Epplin, and C.M. Taliaferro. 2010. Economics of switchgrass and miscanthus relative to coal as feedstock for generating electricity. Biomass Bioenergy 34:1375-1383. doi:10.1016/j. biombioe.2010.04.017

Arundale, R.A., F.G. Dohleman, E.A. Heaton, J.M. Mcgrath, T.B. Voigt, and S.P. Long. 2014. Yields of Miscanthus $\times$ giganteus and Panicum virgatum decline with stand age in the midwestern USA. Glob. Change Biol. Bioenergy 6:1-13. doi:10.1111/gcbb.12077

Bao, M., J.L. Rodríguez, I. Crespo, and K. Lamas. 1996. Miscanthus sinensis plantations in Galicia, NW of Spain. Results and experience over the last three years. Proceedings 9th European Biomass Conference, Copenhagen, Denmark. 24-27 June 1996. Pergamon/Elsevier, Oxford, England. p. 608-612.

Boelcke, B., S. Buech, and S.E. Zacharias. 1998. Effects of Miscanthus cultivation on soil fertility and the soil water reservoir. In: H. Kopetz, T. Weber, W. Palz, P. Chartier, and G.L. Ferrero, editors, Biomass for energy and the environment: Proceedings 10th European Bioenergy Conference, Wurzburg, Germany, 8-11 June 1998. CARMEN, Rimpar, Germany. p. 911-914.

Casler, M.D., K.P. Vogel, C.M. Taliaferro, N.J. Ehlke, J.D. Berdahl, E.C. Brummer, R.L. Kallenbach, C.P. West, and R.B. Mitchell. 2007. Latitudinal and longitudinal adaptation of switchgrass populations. Crop Sci. 47:2249-2260. doi:10.2135/cropsci2006.12.0780
Christou, M., G. Fernandez, G. Gosse, G. Venturi, A. Bridgewater, K. Scheurlen et al. 2004. Bio-energy chains from perennial crops in South Europe. In: W.P. Van Swaaij, editor, Proceedings 2nd World Biomass Conference, Biomass for Energy, Industry and Climate Protection, Rome, Italy. 10-14 May. ETA, Florence, Italy; and WIP, Munich, Germany. http://www.cres.gr/bioenergy_chains/files/ pdf/Articles/5-Rome.pdf (accessed 3 Oct. 2016).

Clifton-Brown, J.C., J. Breuer, and M.B. Jones. 2007. Carbon mitigation by the energy crop, Miscanthus. Glob. Change Biol. 13:2296-2307. doi:10.1111/j.1365-2486.2007.01438.x

Clifton-Brown, J.C., I. Lewandowski, B. Anderson, G. Basch, D.G. Christian, J.B. Kjeldsen et al. 2001. Performance of 15 Miscanthus genotypes at five sites in Europe. Agron. J. 93:1013-1019. doi:10.2134/ agronj2001.9351013x

Curt, M.D. 2009. Miscanthus for biomass. (In Spanish.) Hoja divulgadora 2133. Ministerio de Medio Ambiente y Medio Rural y Marino, Madrid, Spain.

Díaz González, T.E., and J.A. Fernández Prieto. 1994. The vegetation of Asturias. (In Spanish.) Itinera Geobotanica 8:5-242 Servicio de Publicaciones de la Universidad de León, León.

Directive 2009/28/EC. 2009. Directive of the European Parliament and of the Council of 23 April 2009 on the promotion of the use of energy from renewable sources and amending and subsequently repealing Directives 2001/77/EC and 2003/30/EC. Publications Office of the Europena Union. http://eur-lex.europa.eu/eli/dir/2009/28/oj (accessed 3 Oct. 2016).

Dohleman, F.G., and S.P. Long. 2009. More productive than maize in the Midwest: How does miscanthus do it? Plant Physiol. 150:21042115. doi:10.1104/pp.109.139162

Elbersen, H.W., D.G. Christian, N. El Bassam, W. Bacher, G. Sauerbeck, E. Alexopoulou, N. Sharma, I. Piscioneri, P. De Visser, and D. Van Den Berg. 2001a. Switchgrass variety choice in Europe. Aspect of Applied Biol. 65:21-28.

Elbersen, H.W., D.G. Christian, N. Yates, N. El Bassam, G. Sauerbeck, and E. Alexopoulou. 2001b. Switchgrass nutrient composition. In: H.W. Elbersen, editor, Switchgrass (Panicum virgatum L.) as an alternative energy crop in Europe. Initiation of a productivity network. Final report FAIR 5-CT97-3701. Wageningen Univ. \& Res. http://www. switchgrass.nl/en/switchgrass/Publications.htm (accessed 3 Oct. 2016). p. 21-32.

El-Nashaar, H.M., G.M. Banowetz, S.M. Griffith, M.D. Casler, and K.P. Vogel. 2009. Genotypic variability in mineral composition of switchgrass. Bioresour. Technol. 100:1809-1814. doi:10.1016/j. biortech.2008.09.058

Espinoza, L., N. Slaton, and M. Mozaffari. 2006. Understanding the numbers on your soil test report FSA-2118RV. Univ. of Arkansas Coop. Ext. Serv. Little Rock. http://www.uaex.edu/Other_Areas/ publications/PDF/FSA-2118.pdf (accessed 3 Oct. 2016).

Fixen, P.E. 2007. Potential biofuels influence on nutrient use and removal in the U.S. Better Crops Plant Food 91:12-14.

Heaton, E.A., J.C. Clifton-Brown, T.B. Voigt, M.B. Jones, and S.P. Long. 2004b. Miscanthus for renewable energygeneration: European Union experience and projections for Illinois. Mitig. Adapt. Strategies Glob. Change 9:433-451. doi:10.1023/B:MITI.0000038848.94134.be

Heaton, E.A., F.G. Dohleman, and S.P. Long. 2008. Meeting US biofuel goals with less land: The potential of Miscanthus. Glob. Change Biol. 14:2000-2014. doi:10.1111/j.1365-2486.2008.01662.x

Heaton, E.A., T. Voigt, and S.P. Long. 2004a. A quantitative review comparing the yield of two candidate $\mathrm{C} 4$ perennial biomass crops in relation to nitrogen, temperature and water. Biomass Bioenergy 27:21-30. doi:10.1016/j.biombioe.2003.10.005

Hernández Díaz-Ambrona, C.G., and A. Fuertes Sánchez. 2011. Nonfood biomass produced in Spain with the possibility of energy use. (In Spanish.) Info. Técnica Econ. Agraria 107(3):209-225.

Horneck, D.A., D.M. Sullivan, J.S. Owen, and J.M. Hart. 2011. Soil test interpretation guide. EC 1478. Oregon State Univ. Ext. Serv., Corvallis. 
IBM Corp. Released. 2013. IBM SPSS Statistics for Windows, Version 22.0. IBM Corp., Armonk, NY.

IDAE. 2011. Renewable energies plan 2011-2020. (In Spanish.) Ministerio de Energia, Turismo y Agenda Digital. http://www.idae.es/ index.php/id.670/relmenu.303/mod.pags/mem.detalle (accessed 3 Oct. 2016)

INIA. 2009. Heavy metals, organic matter and other parameters of agricultural soils and pastures in Spain. (In Spanish.) Ministerio de Medio Ambiente, Medio Rural y Marino (MARM), Madrid, Spain.

Janer, I., J. Gulías, J. Serra, and J. Cifre. 2016. Comparative study of biomass production and persistence in perennial species for biofuel production. In: M.D. Báez, L. Campo, S. Pereira, M.J. Bande, and J.E. López, editors, Innovación sostenible en Pastos: Hacia una agricultura de respuesta al cambio climático. (In Spanish.) Sociedad Española para el Estudio de los Pastos, A Coruña, Lugo. p. 207-213.

Junta de Extremadura. 1992. Interpretation of soil analysis, foliar and irrigation water. Fertilizer recommendations (basic rules). (In Spanish.) Mundi-Prensa, Madrid, Spain. p. 92.

Kahle, P., L. Belau, and B. Boelcke. 2002. Effects of 10 years of Miscanthus cultivation on different soil properties of mineral soil in North East Germany. (In German, with English abstract.). J. Agron. Crop Sci. 188:43-50. doi:10.1046/j.1439-037x.2002.00530.x

Karp, A., and I. Shield. 2008. Bioenergy from plants and the sustainable yield change. New Phytol. 179:15-32. doi:10.1111/j.1469-8137.2008.02432.x

Khanna, M., B. Dhungana, and J. Clifton-Brown. 2008. Costs of producing Miscanthus and switchgrass for bioenergy in Illinois. Biomass Bioenergy 32:482-493. doi:10.1016/j.biombioe.2007.11.003

Kiniry, J.R., L.C. Anderson, M.V. Johnson, K.D. Behrman, M. Brakie, D.M. Burner et al. 2013. Perennial biomass grasses and the MasonDixon Line: Comparative productivity across latitudes in the southern Great Plains. Bioenerg. Res. 6(1):276-291. doi:10.1007/ s12155-012-9254-7

Kiniry, J.R., M.V. Johnson, S.B. Bruckerhoff, J.U. Kaiser, R.L. Cordsiemon, and R.D. Harmel. 2012. Clash of the titans: Comparing productivity via radiation use efficiency for two grass giants of the biofuel field. BioEnerg. Res. 5(1):41-48. doi:10.1007/ s12155-011-9116-8

Lasorella, M.V., A. Monti, E. Alexopoulou, A. Riche, N. Sharma, S. Cadoux et al. 2011. Yield comparison between switchgrass and miscanthus based on multi-year side by side comparison in Europe. In: M. Faulstich, editor, Proceedings of the 19th European Biomass Conference and Exhibition, Berlin, Germany. 6-10 June 2011. p. 729-733.

Lewandowski, I., and A. Heinz. 2003. Delayed harvest of miscanthusinfluences on biomass quantity and quality and environmental impacts of energy production. Eur. J. Agron. 19:45-63. doi:10.1016/ S1161-0301(02)00018-7

Lewandowski, I., and A. Kicherer. 1997. Combustion quality of biomass: Practical relevance and experiments to modify the biomass quality of Miscanthus $\times$ giganteus. Eur. J. Agron. 6:163-177. doi:10.1016/ S1161-0301(96)02044-8

Lewandowski, I., R. Olsson, W. Bacher, N.L. Huisman, and L. Paavilainen. 1998. Production and use of perennial rhizomatous grasses (PRG) in the energy and industrials sector of Europe. Agric. Syst. 96:224-236.

Linde-Laursen, I. 1993. Cytogenetic analysis of Miscanthus 'Giganteus', and interspecific hybrid. Hereditas 119:297-300. doi:10.1111/j.1601-5223.1993.00297.x

Ma, Z., C.W. Wood, and D.I. Bransby. 2000. Soil management impacts on soil carbon sequestration by switchgrass. Biomass Bioenergy 18:469-477. doi:10.1016/S0961-9534(00)00013-1

Makaju, S.O., Y.Q. Wu, H. Zhang, V.G. Kakani, C.M. Taliaferro, and M.P. Anderson. 2013. Switchgrass winter yield, year-round elemental concentrations, and associated soil nutrient in a zero input environment. Agron. J. 105:463-470. doi:10.2134/agronj2012.0286
Mann, D.G.J., N. Labbé, R.W. Sykes, K. Gracom, L. Kline, I.M. Swamidoss et al. 2009. Rapid assessment of lignin content and structure in switchgrass (Panicum virgatum L.) grown under different environmental conditions. BioEnerg. Res. 2:246-256. doi:10.1007/ s12155-009-9054-x

McLaughlin, S., and A. Kszos. 2005. Development of switchgrass (Panicum virgatum) as a bioenergy feedstock in the United States. Biomass Bioenergy 28:515-535. doi:10.1016/j.biombioe.2004.05.006

Molatudi, R.L., Y. Steinberger, F.Y. Meng, and G.H. Xie. 2015. Effect of switchgrass plantation on soil moisture and nitrogen availability and microbial biomass carbon in a semi-arid ecosystem. Int. J. Agron. Agric. Res. 7(2):130-141.

Monterroso, C., E. Álvarez, and M.L. Fernández-Marcos. 1999. Evaluation of Mehlich 3 reagent as a multielement extractant in mine soils. Land Degrad. Dev. 10:35-47. doi:10.1002/ (SICI)1099-145X(199901/02)10:1<35::AID-LDR319>3.0.CO;2-6

Netherlands Enterprise Agency. 2014. Market opportunities for biomass in Spain. Dutch Ministry of Economic Affairs. http://english.rvo.nl/ sites/default/files/2014/06/Country\%20Monitor\%20Spain\%20 -\%20Final_April\%202014.pdf (accessed 3 Oct. 2016).

Oliveira, J.A., E. Afif, P. Palencia, and J. Gorgoso. 2012. Biomass production and quality of switchgrass (Panicum virgatum L.) in Candás. In: R.M. Canals and L. San Emeterio, editors, Nuevos retos de la ganadería extensiva: Un agente de conservación en peligro de extinción. (In Spanish.) Sociedad Española para el Estudio de los Pastos, Pamplona, Navarra. p. 535-541.

Parrish, D.J., and J.H. Fike. 2005. The biology and agronomy of switchgrass for biofuels. Crit. Rev. Plant Sci. 24:423-459. doi:10.1080/07352680500316433

Quinn, G.P., and M.J. Keough. 2002. Experimental design and data analysis for biologists. Cambridge Univ. Press, Cambridge, UK. doi:10.1017/CBO9780511806384

Sanderson, M.A., N.P. Martin, and P. Adler. 2007. Biomass, energy, and industrial uses of forages. In: R.F Barnes, C.J. Nelson, K.E. Moore, and M. Collins, editors, Forages. The science of grassland agriculture. Vol. II. 6th ed. Blackwell, Ames, IA. p. 635-647.

Sanderson, M.A., J.C. Read, and R.L. Reed. 1999. Harvest management of switchgrass for biomass feedstock and forage production. Agron.J. 91:5-10. doi:10.2134/agronj1999.00021962009100010002x

Sanderson, M.A., R.L. Reed, S.N. McLaughlin, S.D. Wullschleger, B.V. Conger, D.J. Parrish et al. 1996. Switchgrass as a sustainable bioenergy crop. Bioresour. Technol. 56:83-93. doi:10.1016/0960-8524(95)00176-X

Schmer, M.R., M.A. Liebig, K.P. Vogel, and R.B. Mitchell. 2011. Field-scale soil property changes under switchgrass managed for bioenergy. Glob. Change Biol. Bioenergy 3:439-448. doi:10.1111/j.1757-1707.2011.01099.x

Skinner, R.H., W.Zegada-Lizarazu, and J.P. Schmidt. 2012. Environmental impacts of switchgrass management for bioenergy production. Paper 1320. USDA-ARS/UNL. http://digitalcommons.unl.edu/ usdaarsfacpub/1320 (accessed 3 Oct. 2016). p. 129-152.

Steel, R.G.D., and J.H. Torrie. 1980. Principles and procedures of statistics: A biometrical approach. 2nd ed. McGraw-Hill Publ. Co., New York.

van den Berg, D., and P. de Visser. 2001. Thermal conversion of switchgrass. In: H.W. Elbersen, editor, Switchgrass (Panicum virgatum L.) as an alternative energy crop in Europe. Initiation of a productivity network. Final report FAIR 5-CT97-3701. Wageningen Univ. \& Res. http://www.switchgrass.nl/en/switchgrass/Publications.htm (accessed 3 Oct. 2016). p. 48-50.

Whitehead, D.C. 1995. Grassland nitrogen. CAB Int., Wallingford, UK. p. 82-107. 